УДК 336.164

- Фінанси, банківська справа та страхування

JEL Classification: Q18, F65

ЗАЙЦЕВА Л. О. ${ }^{1}$

\title{
ФІНАНСІАЛІЗАЦІЯ В ЗАБЕЗПЕЧЕННІ СТАЛОГО РОЗВИТКУ КОМПАНІЙ
}

DOI: $10.32620 /$ cher.2020.1.04

Постановка проблеми. Стаття присвячена дослідженню проблематики впливу фінансіалізації економіки на сталий розвиток суб'єктів господарювання. Мета статmi - узагальнення і систематизація сучасних фінансових трансформацій капіталу в економічних системах та розробка рекомендацій щодо формування вартісно-орієнтованого підходу до управління трансформаційними процесами капіталу через побудову фінансових відносин щодо забезпечення сталого розвитку компаній. Об'єкт дослідження - сукупність фінансових відносин, що виникають в результаті трансформаційних процесів капіталів в економічних системах та тенденції фінансіалізації на різних рівнях економіки. Методи, використані в дослідженні: способи і принципи наукового пізнання, системний підхід, методи узагальнення індукції, дедукції та синтезу. Основною гіпотезою дослідження стало припущення, що процесс фінансіалізації породжує рух та трансформацію фінансового капіталу, що визначає відтворювальні умови розвитку компанії під впливом ринкових і неринкових факторів. Все це висуває нові вимоги до системи управління фінансовим капіталом і застосування гнучких інструментів управління, здатних виявляти та враховувати декомпозицію вартісних факторів 3 метою оцінки умов сталого розвитку компанії. Виклад основного матеріалу: Зазначено, що фінансіалізація характеризує посилення впливів акціонерного капіталу; сприяє трансформації основних видів капіталу у фінансовий; створює умови для перегляду стратегічних цілей функціонування компанії, віддаючи пріоритет вартісно-орієнтованому підходу управління; відкриває можливості прискорення розвитку за підтримки міжнародних фінансових ресурсів та підвищення конкурентоспроможності вітчизняних емітентів. На основі функціонального перерозподілу збалансованих доходів в контексті посилення тенденцій фінансіалізації доведено можливість інтеграції фінансів до ключових сфер соціально-економічного відтворення для забезпечення сталого розвитку. Продемонстровано трансформацію капіталу компанії в систему побудови фінансових відносин, як прояв фінансіалізації в частині сталого розвитку компанії. Оригінальність та практичне значення дослідження полягає в обгрунтуванні проявів фінансіалізації в діяльності компаній через трасформацію людського, природного, виробничого, інтелектуального, соціально-репутаційного капіталів в фінансовий капітал компанії для забезпечення сталого розвитку. Висновки дослідження: Посилення проявів фінансіалізації формує основу для трансформації фінансового капіталу компанії. Результати дослідження дозволили виявити пріоритетні напрямки забезпечення сталого розвитку вітчизняних підприємств на основі вартісно-орієнтованого підходу до управління.

Ключові слова:

фінансіалізація, сталий розвиток компанії, капітал, трансформація капіталу, фінансові відносини, вартісно-орієнтований підхід управління

\section{FINANCIALIZATION IN PROVIDING SUSTAINABLE DEVELOPMENT OF COMPANIES}

Formulation of the problem: The article is devoted to the study of the problem of the impact of financialisation of the economy on the sustainable development of economic entities. The aim of the research: generalization and systematization of modern financial transformations of capital in economic systems and development of recommendations on formation of value-oriented approach to the management of transformational processes of capital through building financial relations in order to ensure sustainable development of companies. The subject of the research: set of financial relations resulting from the transformation processes of capital in economic systems and tendencies of financialization at different levels of the economy. The methods of the research: methods and principles of scientific knowledge, systematic ap-

1 Зайцева Людмила Олексіївна, канд. екон. наук, доцент кафедри «Фінанси, облік та банківська справа», Луганський національний університет ім. Тараса Шевченка, м. Старобільск, Україна.

Zaitseva Liudmyla, Ph.D, of Economic Sciences, Associate Professor of Finance, Accounting and Banking Department, Luhansk national University. Taras Shevchenko, Starobelsk, Ukraine.

ORCID ID: 0000-0002-9388-5500

e-mail: mila280176@ukr.net 
proach, methods of generalization of induction, deduction and synthesis. The hypothesis of the research: study was the assumption that the process of financialization generates movement and transformation of financial capital, which determines the reproductive conditions of the company under the influence of market and non-market factors. All this puts forward new requirements for the financial management system and the use of flexible management tools that can identify and take into account the decomposition of cost factors in order to assess the conditions of sustainable development of the company. The statement of basic materials: It is stated that financialization characterizes the increase of influence of the share capital, promotes transformation of the main types of capital into financial; creates the conditions for reviewing the strategic goals of the company functioning, giving priority to the cost-oriented management approach; opens up opportunities to accelerate development with the support of international financial resources and increase the competitiveness of domestic issuers. On the basis of the functional redistribution of balanced income in the context of increasing trends in financialization, the possibility of integrating finance into key areas of socio-economic reproduction has been proved to ensure sustainable development. Transformation of the company's capital into the system of financial relations demonstration as a manifestation of financialization in the part of sustainable development of the company is demonstrated. The originality and practical significance of the research: is to substantiate the manifestations of financialisation in the activities of companies through the transformation of human, natural, industrial, intellectual, social and reputational capital into the financial capital of the company to ensure sustainable development. Conclusions. Increasing financialisation forms the basis for the transformation of a company's financial capital. The results of the study allowed us to identify priority areas for ensuring the sustainable development of domestic enterprises on the basis of a cost-oriented approach to management.

Key words:

financialisation, sustainable development of the company, capital, transformation of capital, financial relations, cost-oriented approach of management.

\section{ФИНАНСИАЛИЗАЦИЯ В ОБЕСПЕЧЕНИИ УСТОЙЧИВОГО РАЗВИТИЯ КОМПАНИЙ}

Постановка проблемы. Статья посвящена исследованию проблематики влияния финансиализации экономики на устойчивое развитие субъектов хозяйствования. Цель статьи - обобщение и систематизация современных финансовых трансформаций капитала в экономические системы и разработка рекомендаций по формированию ценностно-ориентированного подхода к управлению трансформационными процессами капитала, путем построения финансовых отношений по обеспечению устойчивого развития компаний. Объект исследования - совокупность финансовых отношений, возникающих в результате трансформационных процессов капиталов в экономических системах и тенденции финансиализации на разных уровнях экономики. Meтоды, использованные в исследовании: способы и принципы научного познания, системный подход, методы обобщения индукции, дедукции и синтеза. Основной гипотезой исследования стало предположение, что процесс финансиализации порождает движение и трансформацию финансового капитала, определяет воспроизводственные условия развития компании под влиянием рыночных и нерыночных факторов. Все это выдвигает новые требования к системе управления финансовым капиталом и применения гибких инструментов управления, способных выявлять и учитывать декомпозиции стоимостных факторов для оценки условий устойчивого развития компании.Изложение основного материала: Отмечено, что финансиализация характеризует усиление влияния акционерного капитала, способствует трансформации основных видов капитала в финансовый; создает условия для пересмотра стратегических целей функционирования компании, отдавая приоритет ценностно-ориентированному подходу управления; открывает возможности ускорения развития при поддержке международных финансовых ресурсов и повышения конкурентоспособности отечественных эмитентов. На основе функционального перераспределения сбалансированных доходов в контексте усиления тенденций финансиализации доказана возможность интеграции финансов в ключевые сферы социально-экономического воспроизводства для обеспечения устойчивого развития. Продемонстрировано трансформацию капитала компании в систему построения финансовых отношений, как проявление финансиализации в части устойчивого развития компании. Оригинальность и практическое значение исследования заключается в обосновании проявлений финансиализации в деятельности компаний путем трансформации человеческого, природного, производственного, интеллектуального, социально-репутационного капитала в финансовый капитал компании для обеспечения устойчивого развития. Bыводы исследования: Усиление проявлений финансиализации формирует основу для трансформации финансового капитала компании. Результаты исследования позволили выявить приоритетные направления обес- 
печения устойчивого развития отечественных предприятий на основе ценностно-ориентированного подхода к управлению.

\section{Ключевые слова:}

финансиализации, устойчивое развитие компании, капитал, трансформация капитала, финансовые отношения, стоимостные-ориентированный подход управления.

Постановка проблеми. Перетворення, які відбуваються в сучасній світовій економіці потребують докорінних змін в розумінні впливу їх наслідків на майбутнє макро та мікро середовища. В зазначених умовах, особливо актуальним $є$ питання сталого розвитку суспільства та бізнес-середовища, через дотримання збалансованості росту економіки, покращення екології та соціальної сфери, 3 врахуванням наслідків сучасної діяльності для майбутніх поколінь. Одним із визначальних імперативів досягнення сталого розвитку $\epsilon$ фінансіалізація усіх ключових видів економічної діяльності. Фінансіалізація в економічних системах пов'язана 3 трансформаціями капіталу. Фінансові трансформації, що є притаманною властивістю сучасних трансформацій в економічних системах вимагають дослідження цих процесів в контексті вартісної концепції капіталу. Мова йде про перехід від витратної до вартісно-орієнтованої моделі управління, що передбачає зміну філософії фінансового менеджменту та його кардинальні трансформації, а також використання сучасних фінансових інструментів.

В умовах сьогодення формування фінансової інфраструктури тісно пов'язане із проектним підходом до побудови системи фінансового забезпечення сталого розвитку. Поглиблення тенденцій фінансіалізації зумовлює перетворення фінансів із посередницької ланки під час становлення реальних соціально-економічних процесів до їх основи.

Аналіз останніх досліджень та публікацій. Одним із перших, Г. Епштейн (G. Epstein) дав визначення фінансіалізації (financialization) у 2001 році, який обгрунтував це явище, як постійно зростаюче значення фінансових ринків, фінансових цілей, фінансових інститутів та фінансових суб'єктів на рівні економіки, суб'єктів бізнесу, а також національних та міжнародних організацій [4]. Проте, надалі, автори: Дж. Аррігі, Р. Бетт, П. Дос Сантос, Г. Кріппнер, В. Мілберг, Г. Магдоф, Ф. Морин, С. Лапавітсас, В. Лазонік, О.
Орхангази, Т. Пеллі, М. О. Салліван, Дж. Смізін, П. Свізі, К. Філіпс, Е. Штокхаммер, та інші висловлювали відмінні точки зору стосовно сутності фінансіалізації. В Україні питанням фінансіалізації присвячені роботи вчених О. Білорус, С. Козьменко, Ю. Осик, В. Лукьянов, Б. Патон, Г. Решетової, Н. Щепочкін та інші.

Значна кількість науковців присвятила свої праці вивченню впливу процесу фінансіалізації на макро рівень, виділив можливі стратегічні рішення з боку державних інститутів, не приділяе уваги дослідженню проблематики впливу фінансіалізації економіки на можливість сталого розвитку країни, особливо на рівні суб'єктів господарювання. Це обумовлює доволі слабкий рівень розвитку вітчизняного фінансового сектору порівняно з відповідними секторами багатьох зарубіжних країн. Однак компанії як частина національного економічного простору можуть істотно вплинути на сталий розвиток країни.

Метою статті $\epsilon$ : визначення структури перерозподілу доходів в контексті посилення тенденцій фінансіалізації, характеристика прояву фінансіалізації в частині сталого розвитку, через трансформацію капіталу в побудові фінансових відносин.

Виклад основного матеріалу дослідження. Фінансіалізація $\epsilon$ узагальнюючим поняттям, що 3 одного боку характеризує процес фінансової глобалізації, а 3 іншого результат його впливу на національну економіку. Як глобальне явище фінансіалізація інтегрує національні ринки капіталів в загальний інвестиційний простір, в рамках якого конкуренція за фінансові ресурси набуває глобального характеру рисунку 1 .

Науковці виділяють різні підходи до розгляду фінансіалізації, що представлені у таблиці 1. В контексті даного дослідження особливої уваги заслуговує акціонерний підхід, $з$ орієнтуванням на вартісно-орієнтоване управління. 


\section{Прояви глобального аспекту фінансіалізації}

- домінування фінансового сектору над реальним;

- зростання фінансової глибини світового економічного простору;

- глобальна фінансова та економічна асиметрія.

\section{Прояви національного аспекту фінансіалізації}

- домінуюча роль фінансової індустрії, фінансового посередництва, бюджетних та навколобюджетних відносин, зростання фінансової глибини міжнародного економічного простору;

- відчутні наслідки соціальної розбалансованості та асоціальних наслідків діяльності фінансових ринків.

\section{Ключові особливості функціонування вітчизняних компаній за умов фінансіалізацї:}

- поширення публічності компаній, прозорості в управлінні та здійсненні операційної діяльності для інвесторів та акціонерів;

- трансформація компаній. Для виходу на міжнародний ринок капіталу з метою залучення значних ресурсів, що є обмеженими в межах внутрішнього фондового ринку, вітчизняні емітенти реєструють холдингову компанію за межами України, хоча сто відсотків активів залишається у розпорядженні українського емітента;

- розширення інструментів залучення додаткових фінансових ресурсів. Міжнародний ринок надає більші можливості у контексті обсягів та строків за допомогою первинних та вторинних публічних розміщень акцій, приватних розміщень акцій, емісії єврооблігацій, синдикованого кредитування тощо;

- використання деривативів для хеджування ризиків;

- якісні зміни стратегії корпоративного управління з акцентуванням менеджменту на забезпечення сталого зростання вартості компанії на ринку;

- вартісно-орієнтований підхід до управління компанією, як показник потенціалу зростання добробуту її акціонерів.

Рисунок 1 - Збалансування проявів фінансіалізації

Джерело: розроблено автором на підставі $[21,25]$

Фінансіалізація, як процес полягає у дослідженні специфіки поширення фінансів на усі внутрішні процеси функціонування суб'єктів господарювання. У свою чергу, фінансіалізація, як інноваційна форма характеризує посилення впливів акціонерного капіталу в частині зростання ролі корпорацій, обгрунтування виправданості трансформації основних видів капіталу у фінансовий.

На практиці, у світі прояви фінансіалізації мають циклічний характер. Зокрема, Дж. Аррігі у праці «Довге двадцяте століття: гроші, влада та витоки нашого часу» ще у 1994-му році виокремив етапи соціальноекономічного розвитку суспільства, зокрема: торгівельну експансію та отримання надприбутків, відтік капіталу із торгівельної у фінансову сферу, фінансову експансію, загострення конкурентної боротьби та кризи [1]. У вказаному контексті, наші сучасники прослідковують зв'язок між системними циклами нагромадження капіталу Дж. Аррігі та довгими хвилями економіки М. Кондратьєва. Характерним $\epsilon$ те, що завершення довгої хви- лі визначається завершенням системного циклу нагромадження капіталу. Тому, визначальним є поєднання тенденцій фінансіалізація iз «точковими» кризовими явищами [20, c. 75].

Фінансіалізація як глобальний тренд розвитку світової економіки, що характеризується зростанням ролі фінансової системи, дає підстави до формування нових стратегічних цілей функціонування компанії. Наразі прибуток втрачає свою важливість у визначенні ефективності дій менеджменту підприємства, даючи поштовх до вартісноорієнтованого підходу управління.

Для українських компаній як тих, що функціонують на граничних ринках капіталу, фінансіалізація мала певні позитивні наслідки, відкриваючи можливості прискорення розвитку за підтримки міжнародних фінансових ресурсів та підвищення конкурентоспроможності вітчизняних емітентів у світі, шляхом випробування на відповідність вимогам[25]. 
Наукові підходи до визначення сутності поняття «фінансіалізація»

\begin{tabular}{|c|c|c|c|}
\hline $\begin{array}{c}\text { Найменування } \\
\text { наукового підходу }\end{array}$ & \multicolumn{2}{|c|}{ Суть наукового підходу } & Автори \\
\hline \multirow[t]{2}{*}{$\begin{array}{l}\text { Акціонерний } \\
\text { підхід }\end{array}$} & \multirow[t]{2}{*}{$\begin{array}{l}\text { Фінансіалізація як } \\
\text { категорія }\end{array}$} & $\begin{array}{l}\text { яка визначає орієнтацію на } \\
\text { акціонерну вартість як режим } \\
\text { корпоративного управління }\end{array}$ & $\begin{array}{l}\text { В. Лазонік[8], } \\
\text { М. О. Салліван[4]. }\end{array}$ \\
\hline & & $\begin{array}{l}\text { яка визначає підвищення ролі } \\
\text { рантьє в економіці }\end{array}$ & $\begin{array}{l}\text { Дж. Смізін[16], } \\
\text { О. Орхангази[12], } \\
\text { Т. Пеллі[14] }\end{array}$ \\
\hline \multirow[t]{2}{*}{$\begin{array}{l}\text { Внутрішньогос- } \\
\text { подарський підхід }\end{array}$} & \multirow[t]{2}{*}{$\begin{array}{l}\text { Фінансіалізація як } \\
\text { процес }\end{array}$} & $\begin{array}{l}\text { вплив на внутрішні процеси } \\
\text { функціонування суб'єктів гос- } \\
\text { подарювання }\end{array}$ & Р. Бетт[2] \\
\hline & & трансформації економіки & Г. Магдоф[9], П. Свізі \\
\hline $\begin{array}{l}\text { Гегемоністичних } \\
\text { підхід }\end{array}$ & \multicolumn{2}{|c|}{$\begin{array}{l}\text { Фінансіалізація як стрімке зростання частки фінан- } \\
\text { сового сектора в економіці }\end{array}$} & $\begin{array}{l}\text { О. Орхангази[13], } \\
\text { Е. Штокхаммер[17], } \\
\text { Дж. Епштейн[5], } \\
\text { В. С. Лук'янов[22] }\end{array}$ \\
\hline $\begin{array}{l}\text { Підхід } \\
\text { накопичення }\end{array}$ & \multicolumn{2}{|c|}{$\begin{array}{l}\text { Фінансіалізація як спосіб отримання прибутку і } \\
\text { залучення інвестицій }\end{array}$} & $\begin{array}{l}\text { Г. Кріппнер[6], } \\
\text { В. Мілберг[10], } \\
\text { Дж. Аррігі[1], П. Дос } \\
\text { Сантос[3], } \\
\text { С. Лапавітсас[7]. }\end{array}$ \\
\hline \multirow[t]{2}{*}{$\begin{array}{l}\text { Інноваційний } \\
\text { підхід }\end{array}$} & \multirow[t]{2}{*}{$\begin{array}{l}\text { Фінансіалізація як } \\
\text { результат }\end{array}$} & $\begin{array}{l}\text { активного розвитку фінансо- } \\
\text { вої торгівлі і розширення спе- } \\
\text { ктра фінансових інструментів }\end{array}$ & $\begin{array}{l}\text { К. Філіпс[15], } \\
\text { Ю. Осик[23], } \\
\text { Н. О. Щепочкін[27] }\end{array}$ \\
\hline & & $\begin{array}{l}\text { посилення впливів акціонер- } \\
\text { ного капіталу в частині зрос- } \\
\text { тання ролі корпорацій }\end{array}$ & Ф. Морин[11]. \\
\hline
\end{tabular}

Найважливішою формою залучення фінансових ресурсів зі світового ринку протягом останніх років було кредитування українських підприємств міжнародним банківським сектором.

На рисунку 2 представлено перерозподіл доходів в контексті посилення тенденцій фінансіалізації. На первинному рівні через державні фінансові установи, шляхом розробки стимулюючої економічної політики, та контролем за ії виконанням, відбувається перерозподіл фінансових ресурсів у вигляді кредитів, інвестицій у діяльність компаній.

Підхід до розробки стимулюючої економічної політики може базуватись на поєднанні макропруденційних політик регулювання фінансових ринків (ринку банківських кредитів), бюджетного фінансування інвестицій, ефективної державної антимонопольної політики і зниженням адміністративного тиску, заохочення малих і середніх компаній.

Макропруденційний підхід до стабілізації і регулювання національних фінансових систем в даний час знаходиться в центрі уваги аналітиків і практиків. Проведення національним банком жорсткого контролю за виконанням банками встановлених нормативів, $\epsilon$ частиною реалізації даної політики. Цілями макропруденційної політики $є$ підвищення стійкості фінансової системи до кризових шоків шляхом створення буферів капіталу і резервів; реалістична оцінка вартості активів і зобов'язань фінансових інститутів 3 урахуванням існуючих ризиків, що дозволяе контролювати взаємовплив фінансових ринкових інститутів, а також виконання обов'язкових нормативів діяльності, щодо секторів фінансових інститутів.

На вторинному рівні компанії при здійсненні господарської діяльності, дотримуючись вартісно-орієнтованого підходу до управління, примножують отримані ресурси та перерозподіляють їх серед акціонерів та працівників. Останні, в свою чергу, на третинному рівні поліпшують свої соціальні умови, підвищуючи показник добробуту. 

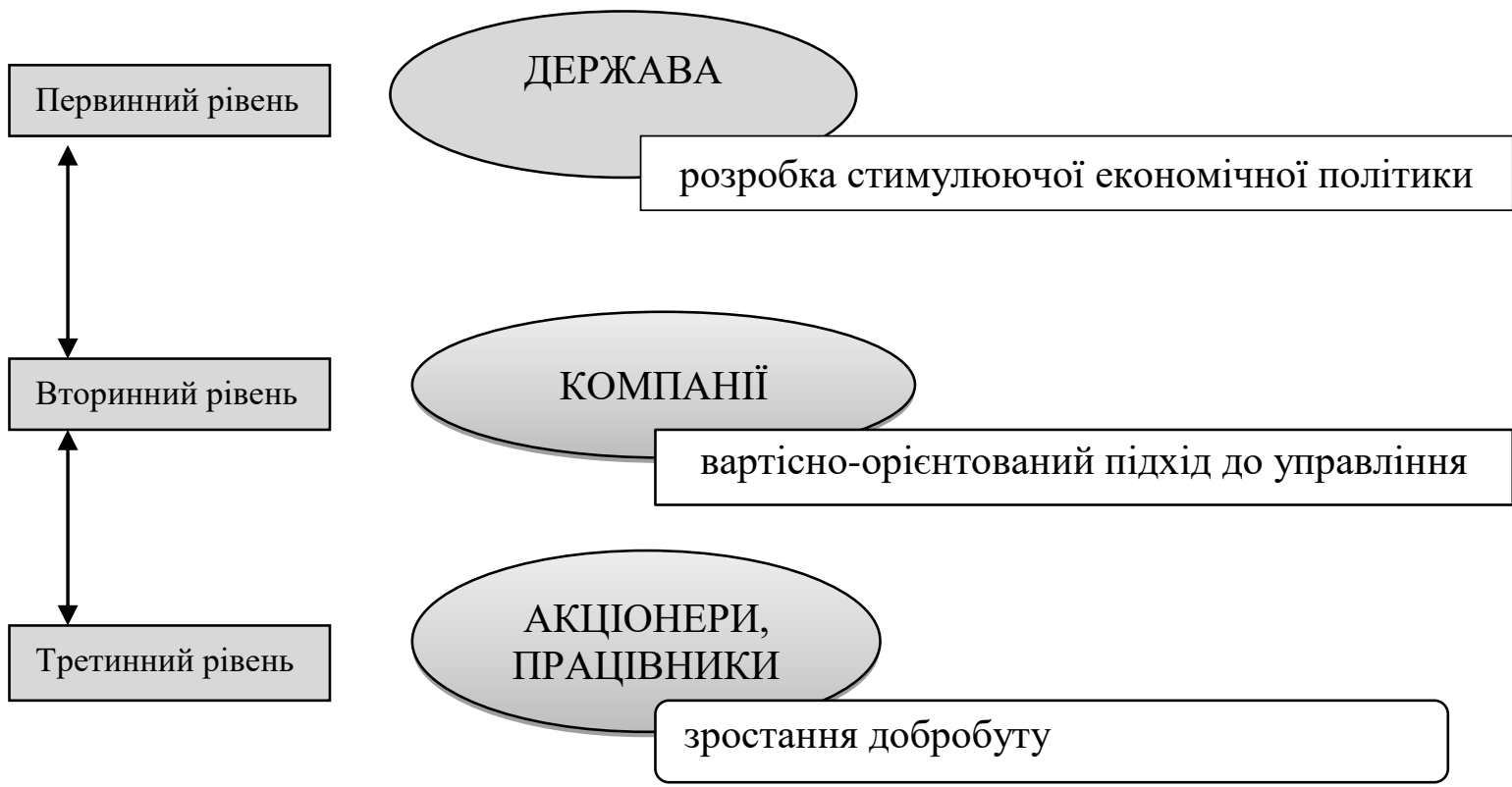

Рисунок 2 - Функціональний перерозподіл збалансованих доходів в контексті посилення тенденцій фінансіалізації

Джерело: розроблено автором

Тобто, в основі тенденцій фінансіалізації лежить інтеграція фінансів до ключових сфер соціально-економічного відтворення для забезпечення збалансованого розвитку при використанні природо-, енерго-, і матеріало- зберігаючих технологій.

В Україні згідно із положеннями Національної парадигми сталого розвитку України financialization трактується, як фінансизація (далі - фінансіалізація), та стосується трансформації природного капіталу у фінансовий [24].

Фінансіалізацію можна визначити домінантою сталого розвитку на національному рівні. Проявом фінансіалізації в частині сталого розвитку $є$ побудова фінансових відносин, які здатні трансформувати людський, природний, виробничий, інтелектуальний, соціально-репутаційний капітал компанії (тобто види капіталу компанії згідно з Міжнародним стандартом інтегрованої звітності[28]) у фінансовий (рис.3).

Трансформація капіталів відбувається в процесі створення компанією вартості в рамках реалізації проектів іiї розвитку. Капітал не $€$ фіксованою величиною і змінюється в часі протягом всієї господарської діяльності, здійснюючи постійну взаємодію між різними видами капіталу. Головною характеристикою та основним призначенням фінансового капіталу є отримання доходу від його використання i вплив на відтворювальні процеси господарюючого суб'єкту. Проте, для того щоб не порушувати відтворювальний процес, необхідно будь-яку економічну зміну та іiї наслідки розглядати 3 позиції динаміки кругообігу фінансових ресурсів і з урахуванням даних змін та ризиків, які супроводжують ці зміни. Посилаючись на відомі теорії капіталу, закономірності кругообігу капіталу підприємства полягають у наступному: єдності споживчої вартості та вартості;пропорційності системи і iї динаміки; об'єктивності вартісної характеристики; завершеності процесу руху функціональних форм капіталу; безперервності та систематичності руху капіталу. Найважливішою умовою ринкових відносин $є$ дотримання закону єдності корисності та вартості, тобто відповідності різних форм капіталу на різних стадіях його руху. В протилежному випадку невідповідність веде до розбалансованості й зниження ринкової вартості активів і підприємства в цілому. [21,С. 80-81]. Це підтверджує перевагу вартісно-орієнтованого підходу до управління в контексті фінансіалізації.

Здійснюючи проекти, спрямовані на розвиток компанії, фінансовий капітал трансформується в природний, людський, інтелектуальний, виробничий, соціальнорепутаційний, в залежності від проекту, а отримані вигоди, в результаті фінансових відносин, у вигляді інвестицій, що покращують показники капіталів. 


\begin{tabular}{|l|}
\hline \multicolumn{2}{|c|}{ Людський } \\
капітал: \\
Підтримка нале- \\
жного рівня здо- \\
ров'я; Освіта; \\
Здобуття додат- \\
кових вмінь та \\
навичок; Поси- \\
лення мотивації \\
індивіда.
\end{tabular}

Інтелектуальний капітал:

Покращення структури інтелектуального капіталу; Відповідність сучасним тенденціям інформатизації; Збільшення витрат на інновації.

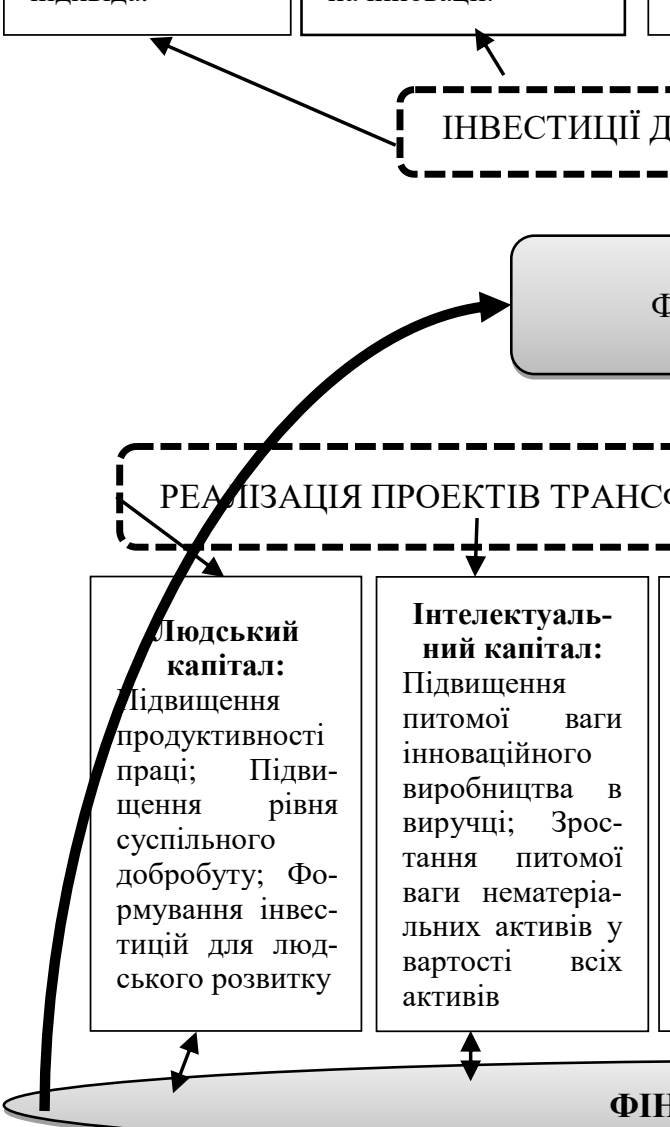

\section{Виробничий капітал:}

Модернізація виробничої інфраструктури; Покращення структури виробничого капіталу; Розширення ринків збиту.
Соціально-репутаційний капітал:

Підтримка стабільності клієнтської бази; Допомога соціально незахищеним групам; Підтримка громадянських проектів, захист навколишнього середовища; Покрашення стандартів соціальної підтримки.

\section{Природний}

капітал:

Покращення

якісної характеристики природних ресурсів; Підтримка екологічних та природоохоронних проектів.

\section{Рисунок - 3 Трансформація капіталу, орієнтована на фінансове забезпечення сталого розвитку компанії Джерело: розроблено автором}

Так, людський капітал при підвищенні продуктивності праці, рівня суспільного добробуту та при формуванні додаткових інвестицій для досягнення цілей людського розвитку; інтелектуальний капітал при підвищенні питомої ваги інноваційного виробництва в виручці, зростанні питомої ваги нематеріальних активів у вартості всіх активів; виробничий капітал при зменшенні енергоємності, трудомісткості, капіталомісткості виробництва, підвищенні ступеню автоматизації та механізації, показників ефективності використання; соціально-репутаційний капітал при підвищенні показників репутації компанії та рейтингових оцінок, показників співпраці 3 постачальниками, скороченні плинності кад- рів; природний капітал при зменшенні величини і структури споживаних природних ресурсів, показників забруднення навколишнього середовища - викиди і відходи, в тому числі в розрахунку на одиницю продукції, робіт, послуг - відбувається перетворення у фінансовий капітал. Грошові кошти фінансового капіталу у вигляді інвестицій для досягнення сталого розвитку направляються на заходи поповнення людського (підтримка належного рівня здоров'я, освіти, здобуття додаткових вмінь та навичок, сприйняття інформації, посилення мотивації), інтелектуального (покращення структури капіталу на відповідність сучасним тенденціям інформатизації, збільшення витрат на інновації; нау- 
ково-дослідні і дослідно-конструкторські роботи, на придбання нових технологій), виробничого (модернізація виробничої інфраструктури, покращення структури капіталу, розширення ринків збиту та асортименту випуску продукції, робіт, послуг), соціальнорепутаційного (підтримка стабільності клієнтської бази, громадянських проектів та захисту навколишнього середовища, допомога соціально незахищеним групам, покрашення характеристик стандартів соціальної підтримки працівників) та природного (покращення якісної характеристики природних ресурсів та підтримка екологічних та природоохоронних проектів) капіталів. Простежується трансформація фінансового капіталу із посередницького руху продуктивного капіталу до його основи. Подібним чином, свого часу, відбувся перехід від простого товарного виробництва до капіталістичного виробництва (трансформація ланцюга товар-гроші-товар до співвідношення гроші-товар-додаткові гроші) [18, с. $17 ; 19$, с. 117].

Висновки та перспективи подальших досліджень. На національному рівні фінансіалізація визначається домінантою сталого розвитку. Посилення тенденцій фінансіалізації на різних рівнях економіки обумовлює необхідність розробки теоретикометодологічного базису для формування фінансової домінанти сталого розвитку компанії. Вихідним положенням дослідження фінансіалізації компанії і $є$ аналіз закономірностей кругообігу та трансформація капіталу для забезпечення сталого розвитку суб'єктів господарювання. Динамічність i гармонійність кругообігу капіталу є основою ефективності господарювання економічної системи та відтворення вартості іiі капіталу. Тому на макрорівні фінансіалізація розглядається як гармонійна побудова фінансових відносин та їх поширення на усі внутрішні процеси, пов'язані 3 діяльністю компанії через трансформацію капіталів (людського, природного, виробничого, інтелектуального, соціальнорепутаційного) для забезпечення іi сталого розвитку.

Наслідками фінансиалізації є періодичні економічні спади та дисбаланси, проявом яких $\epsilon$ відтворення або втрати капіталу. Основними чинниками, що впливають на фінансиалізацію, $\epsilon$ динамічний розвиток та збільшення частки фінансового сектору; диверсифікація фінансових інструментів; глобалізація та інтеграція економічних систем; інтер- націоналізація капіталу та глобалізація ринків в умовах вільної конкуренції та економічної свободи. Індикатором посилення фінансиалізації на рівні компанії, є зміни її вартості. Фінансіалізації через інтеграцію фінансів до ключових сфер відтворення капіталу сприятиме забезпеченню сталого розвитку компаній. Сформульовані рекомендації щодо вартісно-орієнтованого підходу до управління 3 акцентом на фінансові інструменти та індикатори, орієнтовані на зростання та перспективи розвитку компанії.

Подальші дослідження полягають у розробці методологічних засад щодо формування механізму трансформації капіталу в межах посилання фінансіалізації сталого розвитку компаній.

\section{Література}

1. Arrighi G. The Long Twentieth Century: Money, Power, and the Origins of Our Times. London: Verso, 1994.

2. Batt, Rosemary. The Impact of Financialization on Management and Employment Outcomes. 20th Annual John Lovett Memorial Lecture. Ireland: University of Limerick, 2012. 29 p.

3. Dos Santos, P. On the Content of Banking in Contemporary Capitalism. Historical Materialism. 2009. № 17(2). P. 180-213.

4. Epstein G. Financialization, Rentier Interests, and Central Bank Policy. Manuscript, Department of Economics, University of Massachusetts, Amherst, MA, December 2001.

5. Epstein G. Financialization and the World Economy. London: Edward Elgar, 2005. $456 \mathrm{p}$.

6. Krippner Greta.The Financialization of the American Economy. Socio-Economic Review. 2005. Vol. 3, Issue 2. P. 173-208.

7. Lapavitsas C. Financialised Capitalism: Crisis and Financial Expropriation. Historical Materialism. 2009. № 17 (2). P. 114148.

8. Lazonick W. Maximizing shareholder value: a new ideology for corporate governance. Economy and Society. 2000. Vol. 29. № 1. P. 1335.

9. Magdoff H. Stagnation and the Financial Explosion. New York: Monthly Review Press, 1987.

10. Milberg W. Shifting sources and uses of profits: sustaining US financialization with global value chains. Economy and Society. 2008. № 37 (3). P.420-451. 
11. Morin F. A Transformation in the French Model of Shareholding and Management, Economy and Society. 2002. № 29. P 36-53.

12. Orhangazi Özgür. Financialization and the US Economy. Northampton, Massachusetts: Edward Elgar Publishing, 2008.

13. Orhangazi O. Financialisation and capital accumulation in the non-financial corporate sector: A theoretical and empirical investigation on the US economy: 1973-2003. Cambridge Journal of Economic. 2008. № 32. P. 863-886.

14. Palley T. I. Financialization: What It Is and Why It Matters. Levy Economics Institute Working Paper. 2007. № $525.31 \mathrm{p}$.

15. Phillips K. Arrogant Capital: Washington, Wall Street, and the Frustration of American Politics. New York, 1996. 320 p.

16. Smithin J. Macroeconomic Policy and the Future of Capitalism: The Revenge of the Rentiers and the Threat to Prosperity. Aldershot, 1996.

17. Stockhammer Financialization and the Global Economy/ EngelbertStockhammer. University of Massachusetts Amherst Working Paper, 2010. URL: http://www.peri.umass.edu/fileadmin/pdf/working _papers/working_papers_201-250/WP240.pdf

18. Бьюкенен Дж. М. Суспільні фінанси i суспільний вибір: два протилежних бачення держави. Київ, 2004. 170 с.

19. Сщенко П., Самко Н. Фінансіалізаиія у водоверті глобальної економіки. Київ, 2016. $117 \mathrm{c}$.

20. Козьменко С. М., Корнєєв М. В. Періодизація процесу фінансіалізації економіки: вітчизняний та зарубіжний контексти. Економічний часопис-ХХI. 2014. № 9-10. С. 73-76.

21. Костирко Л. А. Фінансовий механізм сталого розвитку підприємства: стратегічні орієнтири, системи забезпечення, адаптація: Монографія. Луганськ: Вид-во «Ноулідж», 2012. С. 80-81

22. Лібанова Е. Сталий людський розвиток: забезпечення справедливості: Національна доповідь. Інститут демографії та соціальних досліджень ім. М. В. Птухи. Умань : Видавничо-поліграфічний центр «Візаві», 2012. 412 c.

23. Лук'янов В. С. Фінансіалізація як прояв глобалізаційних трансформацій. Актуальні проблеми економіки. 2013. № 4 (142). С. 1523.

24. Осик Ю. И. Деглобализация мировой экономики как следствие ее финансиализации. Международныйжурнал прикладних ифундаментальных исследований. 2014. № 1. С. 202-205.

25. Патон Б. Є. Національна парадигма сталого розвитку України / за заг. ред. акад. НАН України, д.т.н., проф., заслуженого діяча науки і техніки України Б. Є. Патона. Вид. 2-ге, переробл. і доповн. К. : Державна установа «Інститут економіки природокористування та сталого розвитку Національної академії наук України», 2016. $72 \mathrm{c}$

26. Решетова Г. В. Фінансіалізація економіки: наслідки для компанії в умовах граничних ринків капіталу. Вісник Львівської комерчійної академії. Серія економічна. - 2014. Вип. 46. C. $50-54$.

27. Україна: шлях до консолідації суспільства: начіональна доповідь / ред. кол.: С. І. Пирожков, Ю.П. Богуцький, Е. М. Лібанова, О. М. Майборода та ін. ; Інститут політичних і етнонаціональних досліджень ім. І. Ф. Кураса НАН України. Київ: НАН України, 2017. 336 с.

28. Щепочкина Н. А. Особенности унификации стандартов регулирования мирового финансового рынка. Конференция «Ломоносов», 2011. URL: http://lomonosovmsu.ru/archive/Lomonosov_2011/1410/13300_189 $0 . p d$

29. Международный стандарт интегри-
рованной http://integratedreporting.org/wpcontent/uploads/2 015/03 /13-12-08-THE-INTERNATIONAL-IRFRAMEWORK.docx_en-US_ru-RU.pdf.

\section{References}

1. Arrighi, G. (1994). The Long Twentieth Century: Money, Power, and theOrigins of Our Times.London: Verso. 136.

2. Rosemary Batt.(2012). The Impact of Financialization on Management and Employment Outcomes. Ireland, University of Limerick, 29

3. Dos Santos, P. (2009). On the Content of Banking in Contemporary Capitalism. Historical Materialism, 17(2), 180-213.

4. Epstein, G. (2001). Financialization, Rentier Interests, and Central Bank Policy, manuscript, Department of Economics, University of Massachusetts, Amherst, MA., December.

5. Epstein, G. (2005). Financialization and the World Economy. London: Edward Elgar, 456.

6. Krippner, Greta. (2005) The Financialization of the American Economy. SocioEconomic Review, 3, 2, 173-208.

7. Lapavitsas, C. (2009). Financialised Capitalism: Crisis and Financial Expropriation. Historical Materialism, (2), 114-148. 
8. Lazonick,W.,\& O'Sullivan, M. (2000) Maximizing shareholder value: a new ideology for corporate governance. Economy and Society, 29, 1, 13-35.

9. Magdoff, H.\&Sweezy, P.

Stagnation and the Financial Explosion. New York: Monthly Review Press.

10.Milberg, W. (2008). Shifting sources and uses of profits: sustaining US financialization with global value chains. Economy and Society, 37 (3), 420-451.

11. Morin, F. (2000). A Transformation in the French Model of Shareholding and Management. Economy and Society, 29, 36-53.

12. Orhangazi, Özgür (2008). Financialization and the US Economy. Northampton, Massachusetts: Edward Elgar Publishing.

13. Orhangazi, O. (2008). Financialisation and capital accumulation in the non-financial corporate sector: A theoretical and empirical investigation on the US economy: 1973-2003. Cambridge Journal of Economic, 32, 863-886.

14.Palley, T. I. (2007). Financialization: What It Is and Why It Matters. Levy Economics Institute Working Paper, 525, 31.

15.Phillips, K. (1996). Arrogant Capital: Washington,Wall Street, and the Frustration of American Politics. New York, 320.

16. Smithin, J. (1996) Macroeconomic Policy and the Future of Capitalism: The Revenge of the Rentiers and the Threat to Prosperity. Aldershot.

17.Stockhammer, Engelbert. (2010). Financialization and the Global Economy. University of Massachusetts Amherst Working Paper. Retrieved from: http://www.peri.umass.edu/fileadmin/pdf/working _papers/working_papers_201-250/WP240.pdf

18. Buchanan, J.M.(2004). Public finance and public choice: two opposing visions of the state. Kyiv, 170.

19. Eshchenko, P., \& Samko, N. (2016). Financialisation in the Whirlpool of the Global Economy. Kyiv, 117.

20.Kozmenko, S. M., \&, Korneev, M.V. (2014). Periodization of the process of

\footnotetext{
Стаття надійшла

до редакції : 29.01.2020 p.
}

financialization of the economy: domestic and foreign contexts. Economic Journal-XXI, 9-10, 7376.

21. Kostirko, L.A.(2012). Financial mechanism of sustainable development of the enterprise: strategic guidelines, systems of support, adaptation. Lugansk: Knowledge Publishing House, 473.

22.Libanova, E. (2012). Sustainable Human Development: Ensuring Justice: A National Report. Uman: Visavi Publishing and Printing Center, 412.

23.Lukyanov, V. S. (2013). Financialization as a Manifestation of Globalization Transformations. Current Problems of Economics, 4 (142), 15-23.

24.Osik, Yu. I. (2014). Deglobalization of the world economy as a consequence of its financialisation. International Journal of Applied and Fundamental Research, 1, 202-205.

25.Paton, B. E. (2016). The National Paradigm for Sustainable Development of Ukraine. Kyiv: State Institution "Institute of Economics of Environmental Management and Sustainable Development of the National Academy of Sciences of Ukraine", 72.

26.Reshetova, G. V, (2014). Financialization of the Economy: Implications for the Company in the Boundary Capital Markets. Bulletin of the Lviv Commercial Academy, 46, 50-54. Retrieved from: http://nbuv.gov.ua/UJRN/Vlca_ekon_2014_46_11.

27. Pirozhkov, S.I., Bogutsky, Yu.P., Libanova, E.M. \&, Mayboroda, O. M. (2017). Ukraine: The Road to Social Consolidation. Kyiv: NAS of Ukraine, 336.

28. Shchepochkina, N.A. (2011) Features of unification of standards of regulation of the world financial market. Conference "Lomonosov". Retrieved from: http://lomonosov-msu.ru/archive/ Lomonosov_2011 / 1410 / 13300_1890.pd

29. The International Integrated Reporting Standard. Retrieved from: http://integratedreporting.org/wpcontent/uploads/2 015/03/13-12-08-THE-INTERNATIONAL-IRFRAMEWORK.docx_en-US_ru-RU.pdf.

Стаття прийнята
до друку: 03.03.2020p.

Бібліографічний опис для цитування :

Зайцева Л. О. Фінансіалізація в забезпеченні сталого розвитку компаній / Л. О. Зайцева // Часопис економічних реформ. - 2020. - № 1 (37). - С. 26-35. 